\title{
Microgram Determination of Bismuth by Sequential High-Fold Chemical-Amplification Reactions
}

\author{
M. S. El-ShahawI and M. M. KaMaL \\ Chemistry Department, Faculty of Science, UAE University, \\ Al-Ain, P. O. Box: 17551, United Arab Emirates
}

Keywords Bismuth(III, IV) determination, amplification reaction, iodometry, spectrophotometry, natural water

Iodometric chemical-amplification procedures with their simplicity and sensitivity are still of special attraction. ${ }^{1-6}$ The extraction of $\mathrm{BiI}_{3}$ with benzene from an $\mathrm{H}_{2} \mathrm{SO}_{4}-\mathrm{KI}$ solution, followed by the reoxidation of $\mathrm{BiI}_{3}$ with bromine, forms the basis of a very sensitive indirect starch-iodine amplification method for bismuth(III) determination. ${ }^{6}$ In this paper, two simple titrimetric and spectrometric methods are described for the determination of bismuth(III) and (V) in aqueous media. The methods are based on the use of sodium periodate to oxidize the bismuth(III) ions to the pentavalent state and a subsequent titrimetric or spectrophotometric determination of the released iodine after the addition of KI.

\section{Experimental}

\section{Apparatus}

A Pye-Unicam double-beam UV-visible spectrophotometer (Model Sp-8-400) with 10-mm quartz cells and a Philips digital $\mathrm{pH}$ meter (Model 9418) were used for absorbance and $\mathrm{pH}$ measurements, respectively.

\section{Reagents and materials}

Analytical reagent-grade chemicals were used without further purification. A bismuth(III) solution $(100 \mu \mathrm{g} /$ $\mathrm{ml}$ ) was prepared by accurately dissolving a weighed amount of $\mathrm{Bi}\left(\mathrm{NO}_{3}\right)_{3}$ in $10 \% \mathrm{HNO}_{3}$ and standardized with $\mathrm{Na}_{2}$ EDTA. ${ }^{7}$ A bismuth(V) solution $(100 \mu \mathrm{g} / \mathrm{ml})$ was prepared by dissolving $0.1234 \mathrm{~g}$ of bismuthic acid in $100 \mathrm{ml}$ of $0.5 \mathrm{~mol} \mathrm{dm}^{-3} \mathrm{KOH}^{8}$, and diluted with distilled water whenever required. A $2.5 \%(\mathrm{~m} / \mathrm{v})$ sodium diethyldithiocarbamate (NaDDC) was freshly prepared in water before use. Sodium thiosulfate solutions $(0.005-$ $\left.0.01 \mathrm{~mol} \mathrm{dm}^{-3}\right)$ and sodium molybdate solution $(5 \% \mathrm{~m} /$ v) were prepared in distilled water. Buffer solutions of pH $2.3-4.7$ were prepared by mixing $200 \mathrm{ml}$ of glacial acetic acid with $100 \mathrm{ml}$ of water, and adjusting the $\mathrm{pH}$ with a saturated solution of sodium acetate. Sodium periodate $(0.35 \mathrm{~m} / \mathrm{v})$ sodium and sulfite $(1 \% \mathrm{~m} / \mathrm{v})$ solutions were freshly prepared in distilled water.
Artificial seawater ${ }^{9}$ with a salinity of about $36 \mathrm{~g} / \mathrm{kg}$ was prepared from demineralized water and salts in the following molar concentrations: $\mathrm{NaCl}, 0.4 ; \mathrm{MgCl}_{2}, 0.029$; $\mathrm{MgSO}_{4}, 0.028$ and $\mathrm{KCl}, 0.009 \mathrm{~mol} \mathrm{dm}^{-3}$.

\section{Recommended procedures}

I. Determination of bismuth(III). Transfer aliquot portions of a bismuth(III) solution containing $10-200 \mu \mathrm{g}$ of the element into a $100-\mathrm{ml}$ conical flask. Add $10 \mathrm{ml}$ of an acetate buffer ( $\mathrm{pH} 2.3-3.5$ ) and 5-ml of sodium periodate solution. Heat the solution mixture on a boiling-water bath for $15 \mathrm{~min}$. Let the reaction mixture cool, and then add 5-ml of sodium molybdate to mask the unreacted sodium periodate, followed by adding a few crystals of $\mathrm{KI}$ at $\mathrm{pH}$ 3. Extract the liberated iodine with two $10-\mathrm{ml}$ portions of $\mathrm{CCl}_{4}$. Collect the extracts in a separating funnel and shake with $10-\mathrm{ml}$ of water containing $1-\mathrm{ml}$ of sodium sulfite to reduce the iodine to iodide. Transfer the aqueous (upper) layer to a $100-\mathrm{ml}$ Erlenmeyer flask, and determine the iodide by one of the following methods:

[48-fold amplification] To the iodide solution add 5-ml of bromine and stir for $3 \mathrm{~min}$. Destroy any excess bromine by dropwise addition of formic acid, add 5-ml of $1 \mathrm{~mol} \mathrm{dm}^{-3}$ sulfuric acid and 3-4 crystals of $\mathrm{KI}$ and determine the released iodine as triiodide by measuring the absorbance of the solution at $350 \mathrm{~nm}$ (ref. 10) against a blank or by titration with $2.5 \times 10^{-3} \mathrm{~mol} \mathrm{dm}^{-3}$ thiosulfate using starch as an indicator. Run a blank to correct any reagent error.

[192-fold amplification] To the iodide solution, add 5$\mathrm{ml}$ of $\mathrm{NaIO}_{4}$, stopper and allow the reaction mixture to stand for $10 \mathrm{~min}$ at room temperature, then place the flask in a boiling-water bath for $20 \mathrm{~min}$. Cool the solution, add $5 \mathrm{ml}$ of sodium molybdate, $10 \mathrm{ml}$ of acetate buffer $(\mathrm{pH} \simeq 3$ ) and $2-3$ crystals of $\mathrm{KI}$ and determine the released iodine as triiodide in the usual manner.

II. Determination of bismuth(V). Transfer aliquot portions of bismuth(V) containing $10-100 \mu \mathrm{g}$ of the element into $100 \mathrm{ml}$ Erlenmeyer flasks, add $2 \mathrm{ml}$ of a sodium sulfite solution to each flask followed by adding 
$5 \mathrm{ml}$ of $\mathrm{HNO}_{3}(1: 1)$. Allow the reaction to stand for $3 \mathrm{~min}$ and evaporate the solution gently on a hot plate until any excess $\mathrm{SO}_{2}$ is completely removed. Add $5 \mathrm{ml}$ of water, and determine the released bismuth(III) using procedure $\mathbf{I}$.

III. Determination of bismuth in seawater. A seawater sample $(400 \mu \mathrm{l})$ acidified to $0.1 \mathrm{~mol} \mathrm{dm}^{-3}$ in hydrochloric acid is filtered through a $0.45 \mu \mathrm{m}$ Millipore filter followed by adding $10 \mathrm{ml}$ of $1 \mathrm{~mol} \mathrm{dm}^{-3}$ tartaric acid, $10 \mathrm{ml}$ of $1 \times 10^{-3} \mathrm{~mol} \mathrm{dm}^{-3}$ of disodium salt of EDTA and $10 \mathrm{ml}$ of $1 \times 10^{-3} \mathrm{~mol} \mathrm{dm}^{-3} \mathrm{NaF}$. Allow the reaction mixture to stand for $10 \mathrm{~min}$, and add $1 \mathrm{ml}$ of sodium sulfite solution, and $2 \mathrm{ml}$ of conc. $\mathrm{HCl}$. Then boil the solution, and finally leave it to cool. The $\mathrm{pH}$ of the solution is adjusted to between $9-10$ by the addition of ammonia, and then transferred into a separating funnel containing $10 \mathrm{ml}$ of $2 \%(\mathrm{~m} / \mathrm{v}) \mathrm{NaDDC}$. The produced Bi-DDC complex is extracted into $10-\mathrm{ml}$ of xylene by shaking for $2 \mathrm{~min}$, as previously reported. ${ }^{11}$ The back extraction of bismuth is then carried out with $5 \mathrm{ml}$ of conc. $\mathrm{HNO}_{3}$, and the contents shaken for $5 \mathrm{~min}$. The aqueous phase is then collected in a $10 \mathrm{ml}$ measuring flask after washing the organic phase with another $5 \mathrm{ml}(2 \times$ 2.5) of conc. $\mathrm{HNO}_{3}$. Finally, determine the total bismuth content following procedure II.

IV. Analysis of bismuth in real samples. Transfer different aliquot volumes $(1-5 \mathrm{ml})$ of a laboratorysynthesized aluminum-bismuth alloy (prepared as described earlier) ${ }^{10}$ to 100 - $\mathrm{ml}$ conical flask. Add $2 \mathrm{ml}$ of saturated $\mathrm{Na}_{2} \mathrm{SO}_{3}, 10 \mathrm{ml}$ of nitric acid $(1: 1)$ and follow the recommended procedure II.

\section{Results and Discussion}

The proposed method for bismuth(III) determination is based principally on its oxidation to the pentavalent state in acid media with sodium periodate according to the following equation:

$$
\mathrm{Bi}^{3+}+\mathrm{IO}_{4}^{-}+2 \mathrm{H}^{+} \longrightarrow \mathrm{Bi}^{5+}+\mathrm{IO}_{3}^{-}+\mathrm{H}_{2} \mathrm{O} .
$$

The released iodate and bismuth(V) can oxidize potassium iodide according to

$$
\mathrm{IO}_{3}^{-}+5 \mathrm{I}^{-}+6 \mathrm{H}^{+} \longrightarrow 3 \mathrm{I}_{2}+3 \mathrm{H}_{2} \mathrm{O}
$$

and

$$
\mathrm{BiO}_{3}{ }^{-}+2 \mathrm{I}^{-}+6 \mathrm{H}^{+} \longrightarrow \mathrm{Bi}^{3+}+\mathrm{I}_{2}+3 \mathrm{H}_{2} \mathrm{O}
$$

Reaction (2) takes place rapidly and proceeds quantitatively in a acidic medium at $\mathrm{pH} \leq 3.5$. Moreover, reaction (3) is a function of the solution $\mathrm{pH}$, as can be predicted from the redox potential concerned. ${ }^{9}$ Preliminary experiments showed that bismuth(V)-KI reacts and proceeds forward quantitatively at $\mathrm{pH}<4$ i.e. bismuth(V) ions release iodine upon a reaction with $\mathrm{KI}$; the released iodine can be determined iodometry or
Table 1 Determination of various amounts of bismuth(III), iodometry (a) and spectrophotometry (b) using 8-fold amplification procedure

\begin{tabular}{cccllll}
\hline \multirow{2}{*}{$\begin{array}{c}\text { Bismuth(III) } \\
\text { taken } / \mu \mathrm{g}\end{array}$} & \multicolumn{2}{c}{ Bismuth(III) found $/ \mu \mathrm{g}$} & & \multicolumn{2}{c}{ Error, \% } \\
\cline { 2 - 3 } \cline { 6 - 7 } & $\mathrm{a}$ & $\mathrm{b}$ & & $\mathrm{a}$ & $\mathrm{b}$ \\
\hline 10 & $10.2 \pm 0.2$ & $10.1 \pm 0.1$ & & 1 & 2 \\
20 & $20.3 \pm 0.3$ & $20.2 \pm 0.2$ & & 1.5 & 1 \\
50 & $51.2 \pm 0.3$ & $50.6 \pm 0.28$ & & 2.4 & 1.2 \\
100 & $101.2 \pm 0.35$ & 101 & \pm 0.1 & & 1.2 & 1 \\
150 & $153 \pm 0.3$ & 151 & \pm 0.20 & & 2 & 0.7 \\
200 & $202 \pm 0.20$ & 201 & \pm 0.25 & & 1 & 0.5 \\
\hline
\end{tabular}

Average \pm standard deviation $(n=5)$.

Error $=$ (average bismuth found $/$ bismuth added $) \times 100$.

spectrophotometrically as triiodide at $350 \mathrm{~nm}$ against reagent blank.

Moreover, the oxidation of bismuth(III) with sodium periodate is $\mathrm{pH}$, temperature and reaction time dependent. Therefore, the effects of these factors were studied on a fixed concentration ( $80 \mu \mathrm{g})$ of bismuth(III) in the $\mathrm{pH}$ range $2.2-5.4$. These solutions were then allowed to react with $5 \mathrm{ml}$ of $\mathrm{NaIO}_{4}$ for different time intervals (5-60 min) and different temperatures (ambient or $100^{\circ} \mathrm{C}$ ) on a boiling-water bath. After cooling, the solutions were adjusted to $\mathrm{pH} 3$ by adding $10 \mathrm{ml}$ of acetate buffer; the excess sodium periodate was masked with molybdate ions at the same $\mathrm{pH}$. The released iodate and bismuth(V)(reaction (1)) were then allowed to react with $\mathrm{KI}(\simeq 40 \mathrm{mg})$, and the liberated iodine was determined by both iodometry and spectrophotometry. The results indicated that, the optimum $\mathrm{pH}$ range for complete oxidation of bismuth(III) with periodate was obtained in the $\mathrm{pH}$ range 2.3-4.0 after boiling the solution on a water bath for $15 \mathrm{~min}$. At $\mathrm{pH} \geq 4$ reactions (1) - (3) proceeded slowly. A $\mathrm{pH}<2.2$ it proceeded rapidly, but the molybdate did not mask the unreacted periodate ions quantitatively, since the molybdateperiodate complex was partially decomposed. Thus, the blank values are erroneously high due to the reaction of the released periodate with iodide. ${ }^{12}$ Fortunately, the $\mathrm{pH}$ values suitable for the quantitative oxidation of bismuth(III) with periodate ions ( $\mathrm{pH} 2.3-3.5$ ) are quite appropriate for masking any excess unreacted periodate. Thus, an acetate buffer solution ( $\mathrm{pH} 3$ ) was added at the beginning of the experiments. Each original bismuth(III) ion release eight equivalents of iodine; i.e. the proposed method affords 8-fold amplification for each one bismuth(III) ion. The developed method was employed for the determination of various amounts of bismuth $(10-200 \mu \mathrm{g})$ iodometrically as well as spectrophotometrically at $350 \mathrm{~nm}$. The results are summarized in Table 1. Satisfactory results were obtained employing iodometric and spectrophotometric procedures with standard deviations in the $0.2-0.35$ and $0.15-0.28$, ranges respectively.

Bismuth(V) can be determined either iodometrically or 
spectrophotometrically employing Eq. (3). The sensitivity and the detection limit of this method can be improved by a prior reduction of bismuth( $V$ ) to bismuth(III), followed by the determination of the produced bismuth(III) element by the 8-fold amplification procedure described earlier. A series of reducing agents was used to reduce $\mathrm{Bi}(\mathrm{V}) \rightarrow \mathrm{Bi}(\mathrm{III})$ quantitatively without interfering with the proposed procedure. Sodium sulfite $(1 \%)$ in acid media was found to be the most convenient reducing agent, where the unreacted sulfite ion can be removed by boiling off sulfur dioxide formed. The determination of various levels $(10-100$ $\mu \mathrm{g})$ of bismuth( $\mathrm{V})$ in aqueous media was carried out and satisfactory results were obtained with a standard deviation in the $0.2-0.5$ range.

An analysis of a binary mixture of bismuth(III) and (V) in an aqueous media was carried out using the proposed procedure. An aliquot mixture was allowed first to react with sodium periodate employing the procedure described for bismuth(III) determination. Another aliquot mixture was allowed to react with $\mathrm{KI}$ at $\mathrm{pH}<3$, followed by a determination of the released iodine. On the basis of these procedures, the volume $\left(V_{1} \mathrm{ml}\right)$ of sodium thiosulfate or the absorbance $\left(A_{1}\right)$ of the released iodine for the first aliquot was equivalent to the sum of bismuth(III)+(V). The volume $\left(V_{2} \mathrm{ml}\right)$ of sodium thiosulfate or the absorbance of the released iodine $\left(A_{2}\right)$ for the second aliquot was equivalent to bismuth(V). Thus the volume $\left(V_{1}-V_{2} \mathrm{ml}\right)$ or the absorbance $\left(A_{1}-A_{2}\right)$ was equivalent to bismuth(III). Satisfactory results were obtained with an absolute error in the $0.5-2.4$ range.

Moreover, the sensity of the proposed 8-fold amplification procedure of bismuth(III) determination could be increased employing the oxidation with bromine water and sodium periodate. The released iodine from Eqs. (2) and (3) is extracted quantitatively upon shaking with two $10-\mathrm{ml}$ portions of $\mathrm{CCl}_{4}$ and shaken with sodium sulfite solution to reduce the iodine to iodide according to the equation ${ }^{13}$

$$
\mathrm{I}_{2}+2 \mathrm{SO}_{3}{ }^{2-}+2 \mathrm{H}_{2} \mathrm{O} \longrightarrow \mathrm{SO}_{4}{ }^{2-}+2 \mathrm{I}^{-}+2 \mathrm{H}^{+} \text {. }
$$

The released iodide in the aqueous (upper) layer is allowed to react with bromine or sodium periodate to produce iodate according to the following equations: ${ }^{13}$

$$
\begin{aligned}
& 3 \mathrm{Br}_{2}+\mathrm{I}^{-}+3 \mathrm{H}_{2} \mathrm{O} \longrightarrow \mathrm{IO}_{3}^{-}+6 \mathrm{HBr} \\
& 3 \mathrm{IO}_{4}^{-}+\mathrm{I}^{-} \longrightarrow 4 \mathrm{IO}_{3}^{-}
\end{aligned}
$$

The released iodate produced from Eq. (5) or (6) is quantitatively determined iodometrically and also spectrophotometry after the addition of KI $(50-70 \mathrm{mg})$. Thus, according to Eq. (5), the overall amplification employing the oxidation of iodide by bromine is 48 -fold while Eq. (6) produces an overall 192-fold amplification of the iodine equivalent to each bismuth(III) element originally present. The proposed two amplification procedures have been successfully for an analysis of
Table 2 Determination of various amounts of bismuth(III)

\begin{tabular}{|c|c|c|c|c|}
\hline \multirow{3}{*}{$\begin{array}{c}\text { Bismuth(III) } \\
\text { taken } / \mu \mathrm{g}\end{array}$} & \multicolumn{4}{|c|}{ Bismuth(III) found $/ \mu \mathrm{g}$} \\
\hline & \multicolumn{2}{|c|}{ 48-fold } & \multicolumn{2}{|c|}{ 192-fold } \\
\hline & a & b & a & $\mathrm{b}$ \\
\hline 5 & $5.1 \pm 0.2$ & $5.0 \pm 0.1$ & $5.0 \pm 0.1$ & $5.0 \pm 0.1$ \\
\hline 10 & $10.1 \pm 0.2$ & $10.1 \pm 0.1$ & $10.1 \pm 0.1$ & $10 \pm 0.2$ \\
\hline 20 & $20.1 \pm 0.2$ & $20.2 \pm 0.1$ & $20.1 \pm 0.1$ & $20.1 \pm 0.3$ \\
\hline 50 & $50.2 \pm 0.3$ & $50.2 \pm 0.1$ & $50.1 \pm 0.2$ & $50.6 \pm 0.2$ \\
\hline 100 & $100.6 \pm 0.4$ & $100.4 \pm 0.2$ & $100.5 \pm 0.3$ & $100.4 \pm 0.3$ \\
\hline
\end{tabular}
by iodometry (a) and spectrophotometry (b) using 48-fold and 192-fold amplification procedures

Average \pm standard deviation $(n=3)$.

$5-100 \mu \mathrm{g}$ bismuth(III). The obtained results are summarized in Table 2 with good accuracy. The spectrophotometric procedure employing 192-fold amplification can be extended to a lower concentration $(\leq 0.1 \mu \mathrm{g})$ of bismuth by the extraction of the released iodine in $\mathrm{CHCl}_{3}$ containing alcoholic $\mathrm{KI}$, and measuring the absorbance of the triiodide at $360 \mathrm{~nm}$, as previously reported. ${ }^{14}$

The absorbance-concentration relationship was found to be linear for $0.3-20 \mu \mathrm{g} \mathrm{ml}^{-1}$ of bismuth(III) or (V) employing 48-fold amplification. A linear calibration graph was also obtained over a concentration range of $0.1-12 \mu \mathrm{g} \mathrm{ml}^{-1}$ at 192-fold amplification for $\mathrm{Bi}$ (III) determination. The optimum concentration range for the effective spectrophotometric determination evaluated by the Ringbom's method ${ }^{15}$ is $5-16 \mathrm{ppm}$ for 48-fold amplification and $1.2-10 \mathrm{ppm}$ for 192 amplification. The relative standard deviation $(n=5)$ was in the range $1.3-1.7 \%$. The detection limit ( $3 \times$ noise) and correlation coefficient were found to be $0.1 \mathrm{ppm}$ and 0.987 for $1-20 \mathrm{ppm}$, respectively.

\section{Application of the proposed method}

The applicability of the proposed procedures for the analysis of bismuth(III) or (V) in tap, polluted potable or seawater and artificial seawater $(0.1-11)$ has been examined employing the recommended procedure (IV) using the standard addition method. Negative results were obtained, indicating the absence of bismuth. In separate experiments water samples spiked with various amounts $(5-50 \mu \mathrm{g})$ of bismuth were analyzed employing procedure (III). Satisfactory results with a relative standard deviation in the range $1.3-1.7 \%(n=3)$ and a correlation coefficient of 0.96 were obtained. The analysis of a very low concentration of bismuth (as low as $(<0.1 \mu \mathrm{g} / \mathrm{ml}))$ in seawater is also possible by the proposed procedure after preconcentration and recovery of bismuth from large sample volume on polyurethane foam column ${ }^{16}$ and a determination of the produced bismuth according to the described procedure II.

A spectrophotometric analysis $(n=3)$ of two weighed samples of bismuth in laboratory synthesized Al-Bi alloy by the proposed 192-fold amplification procedure 
$\left(\mathrm{Bi}_{2} \mathrm{O}_{3} \%=5.7\right)$ was in good agreement with the values obtained by the standard method $\left(\mathrm{Bi}_{2} \mathrm{O}_{3} \%=5.82\right) .{ }^{17} \mathrm{~A}$ relative standard deviation in the $1.7-2.2 \%$ range was obtained.

\section{Effect of foreign ions}

The interference of various ions $\left(\mathrm{Zn}^{2+}, \mathrm{Pt}^{2+}, \mathrm{Sn}^{4+}, \mathrm{K}^{+}\right.$, $\mathrm{Ni}^{2+}, \mathrm{Al}^{3+}, \mathrm{Na}^{+}, \mathrm{Li}^{+}, \mathrm{Co}^{2+}, \mathrm{Fe}^{3+}, \mathrm{Pd}^{2+}, \mathrm{Mo}^{6+}, \mathrm{Cd}^{2+}, \mathrm{Ca}^{2+}$, $\mathrm{Mg}^{2+}, \mathrm{Ba}^{2+}$ and $\mathrm{La}^{3+}$ ) which are commonly in association with bismuth, was investigated at a concentration $(50 \mu \mathrm{g})$ approximately exceeding those normally found in seawater employing the recommended procedure (III). The selectivity of the proposed 8-fold procedure was tested by a determination of a fixed concentration $(10 \mu \mathrm{g})$ of bismuth(III). Satisfactory results were obtained with a percentage recovery of $99.2 \pm 1.2$. Mn(II), Au(I), Ti(I) and $\mathrm{Ru}(\mathrm{III})$ seriously interfered. The determination of a fixed concentration $(40 \mu \mathrm{g})$ of bismuth(III) in the presence of a relatively high excess $(0.5 \mathrm{mg})$ of various ions: $\left(\mathrm{WO}_{4}{ }^{2-}, \mathrm{HCO}_{3}{ }^{-}, \mathrm{Br}^{-}, \mathrm{Cl}^{-}, \mathrm{PO}_{4}{ }^{3-}, \mathrm{SO}_{4}{ }^{2-}, \mathrm{A}_{5} \mathrm{O}_{3}{ }^{-}\right.$, $\mathrm{SbO}_{3}{ }^{-}$and $\mathrm{CO}_{3}{ }^{2-}$ was examined. The percentage recovery of bismuth(III) was $100 \pm 3 \%$.

\section{References}

1. A. M. El-Wakil, A. B. Farag and M.S. El-Nahas, Talanta, 40, 841 (1993).

2. A. B. Farag, M. S. El-Shahawi and E. M. El-Nemma, Fresenius'J. Anal. Chem., 346, 455 (1993).

3. A. M. El-Wakil, A. B. Farag and M. S. El-Shahawi,
Talanta, 36, 783 (1989).

4. A. B. Farag, H. N. Hassan, A. M. Khalil and A. F. Abdel Aziz, Analyst [London], 110, 1265 (1985).

5. A. Townshend and D. T. Burns, Talanta, 39, 715 (1992); J. W. Hamaya and A. Townshend, ibid., 19, 141 (1972).

6. Z. Marczenko, "Separation and Spectrophotometric Determination of Elements", Ellis-Horwood, Chichester, 1986; Z. Marczenko, I. Zotadek and A. Limbach, Chem. Anal. [Warsaw], 14, 741 (1969).

7. A. I. Vogel, "Textbook of Quantitative Inorganic Analysis", 3rd ed., Longman, London, 1972.

8. D. R. Lide, "Handbook of Chemistry and Physics", 2nd ed. Chemical Rubber, 1991.

9. G. Weber, Anal. Chim. Acta, 186, 49 (1986).

10. A. Richard, "Sample Pretreatment and Separation", p. 60, Wiley, New York, 1987; T. Ozawa, Nippon Kagaku Zasshi, 87, 573 (1966).

11. Y. Shijo, M. Mitsuhashi, T. Shimizu and S. Sakurai, Analyst [London], 117, 1929 (1992).

12. D. Burnel, C. R. Acad. Sci., Paris, 261, 1982 (1965).

13. D. Amin, K. Y. Saleem and W. A. Bashir, Talanta, 29, 694 (1982) and references therein.

14. T. C. Ovenston and W. T. Rees, Anal. Chim. Acta, 5, 123 (1951).

15. A. Ringbom, Z. Analyt. Chem., 21 (1938) 332; G. H. Ayres, Analyt. Chem. 21, 652 (1949).

16. Y. A. Gawargious, M. N. Abbas and H. N. A. Hassan, Anal. Lett., 21, 1477 (1988); T. Braun and A. B. Farag, Anal. Chim. Acta, 61, 265 (1972).

17. B. Kasterke, Chem. Anal. [Warsaw], 19, 63 (1974).

(Received December 21, 1994) (Accepted February 6, 1995) 